\title{
China: International Cooperation in Environmental Protection
}

\author{
Nikolaeva Kamila Sergeevna \\ Tashkent State Institute of Oriental Studies, Tashkent, Uzbekistan \\ Email: kamy19@inbox.ru
}

Received December 2014

\section{Abstract}

The paper deals with China's involvement in the process of international environmental protection. The cooperation between China and international environmental organizations is analyzed. This article stresses on such issues as China's cooperation with United Nations Environment Program, Asia-Pacific Economic Cooperation, Association of Southeast Asian Nations, China-Europe and China-Africa Cooperation. The key spheres of China's activity in international environmental protection are examined in this paper. Thus, Chinese government attaches great importance to environmental protection and believes that environmental protection will have a direct impact on the overall situation of China's modernization drive and its long-term development. While promoting economic growth, it has adopted a wide range of measures to strengthen environmental protection.

\section{Keywords}

Environment, Environmental Protection, Sustainable Development, Desertification Prevention, Biodiversity Protection, Ozone Layer Protection, Clean Production, International Cooperation

\section{Introduction}

China stresses international cooperation in environmental protection, and is active in conducting relevant activities with the United Nations (UN) and other international organizations. Over the years, it has dispatched senior delegates to all the meetings of the UN Commission on Sustainable Development, and the World Summit on Sustainable Development and its successive preparatory activities [1]. China and the United Nations Environment Program (UNEP) have conducted fruitful cooperation in the fields of desertification prevention and control, biodiversity protection, ozone layer protection, clean production, cyclical economy, environmental education and training, flood prevention and control on the upper and middle reaches of the Yangtze River, regional sea action plan, and the global action plan for preventing land-sourced pollution and protecting the oceans.

China has also established, with the United Nations Development Program (UNDP), the World Bank, the Asian Development Bank and other international organizations, effective modes of cooperation. China has actively participated in the environmental protection and sustainable development activities under the framework of the Asia-Pacific Economic Cooperation (APEC), and attended all the APEC environment ministerial meet- 
ings. China's efforts for environmental protection have been acknowledged and praised by the international community [1]. The UNEP, the World Bank and the Global Environment Facility granted the "UNEP Sasakawa Environment Prize," "Green Award" and "Global Environment Leadership Award" to the persons in charge of China's environment affairs, and the UNEP also awarded the title "Champion of the Earth" to the leader of the All-China Youth Federation. By the end of 2005, the UNEP had conferred the "Global 500 Award" on 22 units and six persons in China [2].

\section{China and UNEP}

UNEP has had a presence in China since September 2003, when it opened an office in Beijing. Since then, there has been positive development and collaboration between UNEP and China. Some of these areas of mutual cooperation have included:

Policy Dialogue On 11 July 2011 China's Minister of Environment Zhou Shengxian made his first visit to the UN Environment Program (UNEP), where he spoke on international environmental cooperation and the promotion of a Green Economy.

Project Implementation Since 2005, there has existed a tripartite cooperation agreement (China-UNEP-Africa) which saw the first phase implement 4 projects in 17 countries $(2007-2010)$ at a cost of US\$1.8M. The second phase (2011-2013) will involve six projects in 16 different African countries at a cost of US\$6M spread over a period of 3 years. The focus of the second phase will be one river (The Nile), one Lake (Lake Tanganyika) and one Desert (The Sahara) [3].

On 10 May 2014 China's Premier Li Keqiang said China would deepen cooperation with UN agencies to boost green development, address climate change, so as to promote the world's sustainable development. The visiting Chinese leader made the remarks during talks with Achim Steiner, executive director of the UN Environment Program (UNEP), and Joan Clos, head of the UN Human Settlements Program (UN-Habitat). Both agencies were headquartered in Nairobi [4].

Hailing the UNEP's and the UN-Habitat's efforts to better the environment, development of the world as well as people's livelihood, Li said China, member of the two UN agencies, always supports their work and has carried out extensive, effective cooperation with them.

The Chinese government is making strides to advance the construction of ecological civilization, realize sustainable development which coordinates economic growth with social and environmental consideration, while the process of new-type urbanization is also at a pivotal stage in China, Li noted. To enhance cooperation with the two UN bodies and experience-sharing with other countries for global sustainable development, China will continue to boost green growth, improve environment management and promote South-South cooperation on environmental protection and climate change, he said.

The UNEP's Steiner, for his part, lauded China's work to promote green economy and ecological civilization, saying China is an example for other countries in that regard, and that its important contribution to the world environment and development cause is appreciated.

\section{China and Rio +20}

1. At the UN meeting on Sustainable Development in June 2012 in Rio de Janeiro, Brazil, China's Premier Wen Jiabao announced that China will contribute US\$6 million to a UNEP trust fund for projects and activities that help developing countries raise their capacity for environmental protection. He also promised that China will make available 200 million yuan (US \$31.7 million) for a three-year international project to help small island countries, least developed countries and African countries tackle climate change [3]. China's Premier also proposed improving the mechanism of global governance to promote sustainable development, stressing that the United Nations should play a leading role in developing an effective institutional framework for sustainable development.

2. Also at Rio + 20, UNEP worked together with the Xinhua News Agency, to hold the Green Economy and Sustainable Development Summit and "China-in-Action Environmental Protection Achievements" Photo Exhibition. The Summit focused on the theme of "Global Sustainable Development" and presented the development course of China's Green Economy. Ambassador Sha Zukang, UN Under-Secretary-General, the Secretary General of Rio +20 , UN Under-Secretary General and UNEP Executive Director Achim Steiner, Mr. Francisco Gaetani, Executive-Secretary of the Brazilian Ministry of Environment, and Mr. Li Jinzhang, China's Ambas- 
sador to Brazil attended the forum and delivered welcoming remarks.

3. UNEP's Report “Towards a Green Economy: Pathways to Sustainable Development and Poverty Eradication" was also launched at the Rio +20 meeting. It was a collaborative effort by UNEP and Tongji University in Shanghai. Tongji University, through the UNEP-Tongji Institute of Environment for Sustainable Development (IESD), mobilized a multidisciplinary team of distinguished experts in China to translate the various chapters of the 600-page report. The English version of the report was launched by Mr. Steiner in Beijing in November 2011.

4. Rio +20 Global Town Hall: UNEP-ICLEI Sustainable Urban Development Day with Special Focus on China Co-organized by UNEP and ICLEI and sponsored by the Chinese Entrepreneurs Union (CEU), the "Cities and Sustainable Development" Forum was successfully held at the Rio +20 Global Town Hall. The session opened the debate on how Chinese cities can enhance resiliency, attain low carbon growth, build smart infrastructure and foster a green urban economy. Mr. Zhang Jianfei, Mayor of Changsha city in southern Hunan province, has been actively working to become an eco-city by, among other initiatives, building more bike lanes and hiking trails.

\section{China and Environmental Cooperation}

So far, China has acceded to more than 50 international conventions on environmental protection [5], and has been active in performing the obligations stipulated in these conventions, which include the United Nations Framework Convention on Climate Change and its Kyoto Protocol, the Montreal Protocol on Substances That Deplete the Ozone Layer, the Rotterdam Convention on the Prior Informed Consent Procedure for Certain Hazardous Chemicals and Pesticides in International Trade, the Stockholm Convention on Persistent Organic Pollutants, the Convention on Biological Diversity, the Cartagena Bio-safety Protocol, and the United Nations Convention on Combating Desertification [2].

The Chinese government has compiled the State Report of the People's Republic of China on Sustainable Development and the China Action Program for Sustainable Development in the 21st Century, and made clear the key fields and action plans of sustainable development for the early 21 st century [5]. It has approved the China State Plan on Gradually Eliminating Substances That Deplete the Ozone Layer, drawn up more than 100 policies and measures in relation to the protection of the ozone layer, built development and production bases for products that can substitute ozone-layer-depleting substances, and other environmentally-friendly products, and met the phasing-out target set in the Montreal Protocol. According to a World Bank estimate, the amount of ozone-layer-depleting substances that China has eliminated accounts for 50 percent of the total amount eliminated by all the developing countries. The Chinese government hosted in Beijing the fifth meeting of the conference of the signatory states to the Vienna Convention for the Protection of the Ozone Layer and the 11th meeting of the conference of the signatory states to the Montreal Protocol, which adopted the Beijing Declaration and Beijing Amendment, respectively.

China has consolidated and promoted its cooperation with neighboring countries and regions involved, and actively participated in the construction of a regional cooperation mechanism. Together with Japan and the Republic of Korea (ROK), it has established a mechanism for environment ministers to meet to hold regular policy exchanges and discussions of environmental issues of common concern. After the launching of the Greater Mekong Sub-region (GMS) Environmental Cooperation mechanism, the first GMS environment ministers' meeting was successfully held in 2005, which spelled out the biodiversity conservation corridor program for the sub-region and other cooperative projects. Environmental cooperation under the mechanisms of the Association of Southeast Asian Nations (ASEAN) and China $(10+1)$ and ASEAN and China, Japan and the ROK $(10+3)$ has started. At the proposal of the Chinese government, the first Environment Ministers' Meeting (EMM) of the Asia-Europe Meeting (ASEM) was convened in 2002 [2], which released the Chairman's Statement of ASEM EMM and reached agreement about the basis, potential and principle of Asia-Europe environmental cooperation, and defined the key fields and priorities for such cooperation. In recent years, the China-Europe mechanism of ministerial dialogue on environmental policy and the meeting mechanism of China-Europe environment liaison officers have been set up, and the first China-Arab Cooperation Conference on the Environment was held earlier this year.

China has been active in bilateral cooperation in environmental protection. It has signed bilateral agreements or memorandums of understanding on such cooperation with the United States, Japan, Canada, Russia and 38 
other countries, and signed bilateral agreements or memorandums of understanding on nuclear security cooperation with 11 countries [6]. It has made considerable progress in its wide exchanges and cooperation with others regarding environment policies and regulations, pollution prevention and control, biodiversity protection, climate change, sustainable production and consumption, capacity construction, model projects, environmental technology and environmental industries. In addition, it has carried out several environmental cooperation programs with the European Union, Japan, Germany, Canada and nine other countries or international organizations with bilateral assistance gratis. China is also active in environmental cooperation and exchanges with developing countries. To support the follow-up action of the China-Africa Cooperation Forum, China has sponsored the thematic activity of China's Environmental Protection Oriented Towards Africa. In 2005, China and the UNEP jointly hosted China-Africa Environment Cooperation Conference [7], and the Chinese government has organized courses of Workshop on Water Pollution and Water Resources Management for African Countries, helping African countries with environmental training.

\section{UNEP-China-Africa Cooperation}

The 14th African Ministerial Conference on the Environment (AMCEN) [3] held a side event on UNEP-ChinaAfrica Cooperation on the Environment. The event, which was part of the overall meeting of AMCEN, which took place in Arusha, Tanzania, was organized to inform the participants about the objectives, achievements, major outcomes as well as opportunities provided by the UNEP-China-Africa Cooperation Program on the Environment in the context of an inclusive Green Economy and Sustainable Development in Africa.

Starting from 2008, UNEP has established, with the Ministry of Science and Technology of China (MOST), a cooperation agreement to build the capacity of African countries in the fields of ecosystem management, disaster reduction, climate change adaptation and renewable energy [8]. This is known as the UNEP-China-Africa Cooperation Program on the Environment. The Program also aims to promote, through UNEP's Regional Office for Africa (ROA), interventions within the UNEP South-South Cooperation Exchange Mechanism.

Under ROA's coordination, four demand-driven projects, which cover areas such as shared water resources monitoring, waste water treatment and re-use, early warning systems for droughts and adaptation and rainwater harvesting, were implemented in Africa in Phase I of the UNEP-China-Africa Cooperation Program. In November 2011, two more projects were added. Currently, the Program has entered a new phase, around the theme "One River, One Lake, One Desert", targeting the Nile River, Lake Tanganyika and the Sahara Desert [8].

Dr. Mohamed Abdel-Monem, the Regional Team Leader for Ecosystem Management of ROA and UNEP's focal point for the Program, said: "ROA/UNEP has been acting as the bridge between China and African countries. In addition to its coordinating role, UNEP also provides technical support to the implementation of the projects in partnership with the national teams and Chinese institutes."

According to Professor Li Fengting, the Deputy Dean of the UNEP-Tongji Institute of Environment for Sustainable Development (IESD) in Shanghai, China, the six projects under the Program have been implemented in 16 African countries. Objectives of the projects are achieved through joint research, training workshops, visiting scholar programs, pilot projects and educational programs, among others. The projects, funded by MOST, are jointly implemented by technical institutes in China and the participating countries in Africa. In addition, he pointed out that there are scholarships for African students to study in Tongji University.

AMCEN is a permanent forum where African ministers of the environment discuss the environment of the continent. The session consisted of meetings of the Expert Group which were followed by a ministerial segment. The conference was attended by representatives from 45 AMCEN member States at the level of Vice President (Comoros), Ministers (25), Permanent Secretaries, Ambassadors, and leading African climate change negotiators, high level experts from ministries of environment. Those who attended included representatives of international organizations, secretariats of various environmental conventions, including the Deputy Executive Secretary ECA, Executive Secretary of UNCCD, Executive Secretary of UNFCCC, the Special Representative of the Secretary-General for Disaster Risk Reduction (UNISDR), the United Nations Office for Disaster Risk Reduction (UNISDR), Chief Executive Officer and Chairperson of GEF, financial institutions, research institutes, intergovernmental and non-governmental organizations and youth groups. The European Union was represented by the Commissioner for Climate Action.

\section{Conclusion}

The Chinese government attaches great importance to environmental protection. It believes that environmental 
protection will have a direct impact on the overall situation of China's modernization drive and its long-term development, and considers environmental protection an undertaking that will not only benefit the Chinese people of today but also their children and grandchildren. While promoting economic growth, it has adopted a whole array of measures to strengthen environmental protection. Especially in recent years, the Chinese government, with the scientific outlook on development as the guiding principle of environmental protection, has adhered to focusing on preventive measures, comprehensive control and overall progress with breakthroughs at some key points, and worked hard to solve conspicuous environmental problems threatening people's health. At the same time, it has continued its efforts for institutional innovation, relied on scientific and technological advances, strengthened the legal system of environmental protection, and brought into full play the initiative of people of all walks of life.

\section{References}

[1] Wang, Y., Morgan, R. and Cashmore, M. (2003) Environmental Impact Assessment of Projects in the People's Republic of China: New Law, Old Problems. Environmental Impact Assessment Review, 23, 543-579. http://dx.doi.org/10.1016/S0195-9255(03)00071-4

[2] http://www.china.org.cn/english/2006/Jun/170355.htm\#11

[3] http://www.unep.org/rso/ProgrammesActivities/UNEP-ChinaCooperation/UNEP-China-AfricaCooperationontheEnvir onment/tabid/105388/Default.aspx

[4] http://english.people.com.cn/90883/8623629.html

[5] Bessarabova, G.D. and Ganshina, V.G. (2009) China. Harmony and Sustainable Development Problems. Moscow, 58.

[6] Gelbras, V. (2007) The CPR's Success and Its Cost in Globalization Conditions. Asia and Africa Today, 7, $20-30$.

[7] Edmonds, R.L. (2004) Managing the Chinese Environment. Studies on Contemporary China, Oxford University Press.

[8] Kozlov, A.A. (2004) China and International Cooperation in Environmental Protection. China in the World and Regional Politics, Moscow, 53-61. 